\title{
Intimidasi Terhadap Jurnalis Daerah Ditinjau dari Faktor Pendorong dan Implikasi Psikologis
}

\author{
Imam Nuraryo \\ Institut Bisnis dan Informatika Kwik Kian Gie \\ imam@kwikkiangie.ac.id
}

\begin{abstract}
Journalists are vulnerable to violence and intimidation. Violence against members of the press, are in fact, has a tendency of increasing in this reform era. The purpose of the research is to investigate the type of violence which afflicts local journalists, factors that causes intimidation and several implications to local journalists in city 'A'. Conceptual framework used in the research is verbal and nonverbal abuse concept/ theory. Pierre Bourdieu's thoughts regarding symbolic violence that are the result of power relations are also used in this study. The research method used is qualitative. The results of this study indicate that journalists from the area often receive intimidation in the form of yelling, scolding, shouting, slapping and even rejection. The journalists often even receive terror through text messages and death threats. The factor that encourages violence in journalists is that journalists themselves are often careless and act rashly in reporting. The implications of this form of intimidation are psychological trauma, vengeful feelings and excessive anxiety. Suggestions from the results of this study is the need for journalists to increase competence in covering or investigating news, their knowledge in protection law in their task, and controlling their own emotion and psycological traumatic post intimidation.
\end{abstract}

Keywords: Intimidation; violence; verbal communication; non verbal communication; local journalists

\begin{abstract}
Abstrak
Para jurnalis rentan menghadapi kekerasan dan intimidasi. Kekerasan terhadap insan pers, justru di era reformasi ini cenderung semakin meningkat.Tujuan penelitian ini adalah untuk mengetahui jenis-jenis kekerasan yang menimpa pada para jurnalis lokal, faktor-faktor yang mendorong terjadinya intimidasi pada wartawan lokal, dan implikasinya pada wartawan tersebut di Kota "A" . Kajian konseptual yang mendasari penelitian ini adalah konsep kekerasan verbal dan non verbal. Pemikiran dari Pierre Bourdieu mengenai kekerasan simbolik yang merupakan hasil dari relasi kuasa juga digunakan dalam penelitian ini. Metode penelitian yang digunakan adalah kualitatif. Hasil penelitian ini menunjukkan bahwa para jurnalis dari daerah tersebut sering menerima intimidasi berupa bentakan, cacian, teriakan, tamparan bahkan pengusiran. Para jurnalis tersebut bahkan sering mendapatkan teror melalui SMS dan ancaman pembunuhan. Faktor yang mendorong adanya kekerasan pada jurnalis adalah karena para jurnalis itu sendiri seringkali ceroboh dan bertindak gegabah dalam peliputan. Implikasi dari bentuk intimidasi ini adalah trauma secara psikologis, rasa dendam dan perasaan cemas yang berlebih. Saran dari hasil penelitian ini perlunya peningkatan kompetensi dalam peliputan bagi para jurnalis daerah, pemahaman dalam upaya perlindungan hukum bagi para jurnalis saat meliput, dan pelatihan dalam pengendalian emosi serta trauma sebagai akibat dari perlakuan intimidasi.
\end{abstract}

Kata Kunci: Intimidasi; kekerasan; komunikasi verbal; komunikasi non verbal; jurnalis daerah

Korespondensi: Dr. Imam Nuraryo, M.A. (Comms), Institut Bisnis dan Informatika, Jl. Yos Sudarso Kav 87, Sunter, Jakarta Utara 14350, Telp. 6222165307062, Email: imam@kwikkiangie.ac.id

Menyerahkan: Oktober 2019, Diterima: Mei 2020, Terbit: Juli 2020

ISSN: 2549-0559 (cetak), ISSN: 2549-1946 (online), Website: http://jurnal.unpad.ac.id/kajian-jurnalisme 
Volume 04 Nomor 01 Tahun 2020

DOI: $10.24198 / j k j . v 4 i 1.24134$

\section{PENDAHULUAN}

Demokrasi Indonesia sejak reformasi pada tahun 1998 telah mengantarkan episode baru kebebasan pers di negeri ini. Para jurnalis atau wartawan mendapatkan kekuatan yang sangat besar dalam memberitakan realita disekitar tanpa rasa takut, karena hak-haknya telah dilindungi. Namun demikian, situasi ini juga dapat dikatakan dapat membawa kecemasan bagi sebagian pihak mengenai "kebebasan pers yang kebablasan". Profesi jurnalis menuntut tanggung jawab yang tinggi dalam melaksanakan tugasnya. Untuk itu, mereka memerlukan standar kompetensi yang memadai.

Apabila tidak diiringi kompetensi yang tinggi, para jurnalis selain tidak dapat mengerjakan tugasnya dengan profesional, juga akan rentan menghadapi kekerasan dan intimidasi. Kekerasan terhadap insan pers, justru di era reformasi ini cenderung semakin meningkat. Pada tahun-tahun awal di masa reformasi. Berdasarkan data dari Aliansi Jurnalis Independen (AJI) tujuh tahun silam, mencatat bahwa terdapat lebih dari lima puluh kasus kekerasan pada jurnalis yang terjadi rentang waktu Desember 2011 - Desember 2012 (Independen, 2013). Data dari Lembaga Bantuan Hukum (LBH) Jakarta juga menunjukkan bahwa dalam kurun delapan tahun, sejak tahun 2003, tercatat sebanyak 467 kasus kekerasan wartawan/jurnalis (Hakim, 2013).

Pada rentang waktu tahun 2018 - 2019, terdapat berbagai peristiwa kriminalisasi terhadap jurnalis di daerah. Misalnya kasus pelaporan jurnalis Batamnews.co.id ke polisi, karena alasan pencemaran nama baik secara pribadi oleh salah seorang pejabat di Kota Batam, pada bulan Februari 2018 lalu. Dimana seharusnya, pejabat yang bersangkutan melakukan hak jawab terlebih dahulu untuk melakukan klarifikasi ke Dewan Pers, dan bukan justru melaporkannya ke pihak kepolisian (Gumilang, 2018).

Belum lagi kasus mengenai kriminalisasi dua orang jurnalis Palangkaraya bulan Juli tahun 2019. Dua jurnalis bernama Arliandie dan Yundhi, dilaporkan ke polisi oleh sebuah perusahaan besar swasta, gegara pemberitaan yang ditulis oleh kedua jurnalis tersebut dianggap menyudutkan perusahaan tersebut. Padahal hal tersebut merupakan produk jurnalistik yang sifatnya merupakan kritikan dan kontrol sosial (Warta Ekonomi Online, 2019).

Kekerasan fisik juga dialami oleh para peliput pada peristiwa tanggal 21-22 Mei 2019. Dikutip dari detik.com yang terbit pada tanggal 26 Mei 2019, terdapat 20 orang jurnalis yang menjadi korban kerusuhan. Kekerasan yang diterima oleh pihak jurnalis tersebut dilakukan oleh pihak massa dan kepolisian. Bentuknya berupa pengusiran, penghalangan, pemukulan hingga perampasan alat saat liputan. Disamping itu, terdapt indikasi adanya upaya massa melalui media sosial untuk mempersekusi jurnalis (Rahayu, 2019).

Kasus terakhir adalah bulan September 2019 lalu, yakni Gerakan "Gejayan Memanggil 2" yang menimpa empat orang jurnalis Kompas.com yakni diantaranya adalah Nibras Nada Nailufar. Beliau diintimidasi pada saat merekam perilaku polisi yang melakukan kekerasan terhadap seorang warga di kawasan Jakarta Convention Centre. Ada polisi yang melarang korban merekam gambar dan memaksanya menghapus rekaman video kekerasan tersebut. Selanjutnya kekerasan juga dialami oleh Vanny El Rahman, jurnalis dari IDN Times. Beliau dipukul dan diminta menghapus foto dan video rekamannya yang berisi kekerasan yang dilakukan oleh polisi terhadap para demonstran di sekitar jembatan layang Slipi Jakarta. Hal ini menandaskan bahwa negara telah gagal merawat demokrasi karena menyerang kebeasan berpendapat dan berekspresi (Maharani, 2019).

Sejarah mencatat bahwa lebih dari dua puluh tahun yang silam, kasus kekerasan pada jurnalis yang sangat fenomenal yakni pembunuhan wartawan harian Bernas Yogya, Fuad Muhammad Syafrudin alias Udin. Beliau dibunuh pada tanggal 16 Agustus 1996. Sampai saat ini, kasus tersebut tidak menemui titik terangnya. Kasus ini sebenarnya hanyalah setitik mungil 
dari bentuk kriminalisasi dan kekerasan, yang merupakan perilaku intimidatif terhadap jurnalis lokal di negeri ini. Sudah seharusnya jurnalis dalam menjalankan tugasnya, harus mendapatkan perlindungan hukum sebagiamana yang diatur dalam undang-undang.

Terdapat berbagai faktor yang menyebabkan terjadinya tindakan kekerasan yang dialami oleh jurnalis. Salah satunya kesalahpahaman narasumber dalam memahami pertanyaan yang diajukan oleh jurnalis yang berujung dengan rasa ketersinggungan dari narasumber. Disamping itu, perilaku jurnalis yang dianggap tidak sopan dalam menyampaikan pertanyaan pada narasumber, pertanyaan yang dianggap mengintimidasi, atau narasumber menganggap jurnalis berniat untuk membuka "aib" atau melakukan investigasi, layaknya seorang polisi. Pada akhirnya, hal-hal tersebut juga mermuara pada percekcokan antara jurnalis dan narasumber. Padahal sejatinya, proses jurnalisme ini seharusnya merupakan hasil dari kerjasama insan pers dan sumber berita dalam memberikan informasi yang tepat, akurat dan jujur yang akan disajikan bagi masyarakat.

Oleh karena seringnya peristiwa kekerasan di kalangan pers, tidak jarang memicu perasaan takut dan cemas, khususnya bagi yang bercita-cita menjadi jurnalis yang profesional. Sebagian dari mereka akan mengecil nyalinya pasca mendapatkan kabar - kabar mengenai kasus-kasus kriminalisasi dan tekanan yang ditujukan pada wartawan saat mereka menjalankan tugas di lapangan. Memang benar, setiap pekerjaan memiliki resiko, akan tetapi resiko berupa kekerasan itu adalah sesuatu hal yang tidak diperhatikan.

Apabila kekerasan ini diabaikan secara terus menerus, maka tak ayal dimasa mendatang, tak akan ada lagi insan pers yang profesional yang tertantang untuk membangun negara ini. Jurnalis yang profesional tentu memahami bahwa di dalam menjalankan tugasnya, harus memahami kode etik jurnalistik dan undang-undang yang melindunginya, yakni UndangUndang nomor 40 tahun 1999. Dengan adanya perlindungan hukum semacam itu, ditambah dengan peningkatan kompetensi dalam peliputan, maka para jurnalis dapat bekerja secara maksimal sesuai dengan aturan yang berlaku dan tanpa diiringi rasa cemas. Kasus yang akan diangkat dalam penelitian ini adalah penganiayaan seorang jurnalis seusai meliput kasus dugaan pungli di salah satu tempat layanan publik di kota "A". Penganiayaan tersebut terjadi pada saat jurnalis tersebut berada di lokasi sedang melakukan peliputan, secara tiba-tiba bermunculan beberapa orang yang merupakan oknum staf dari instansi tersebut. Oknum tersebut melontarkan kata-kata yang tidak pantas, merampas telepon seluler milik jurnalis tersebut, disertai dengan tamparan yang mendarat pada pipi sang jurnalis.

Penelitian ini mencoba untuk menggali hal-hal apa saja jenis intimidasi yang diterima oleh para jurnalis lokal, faktor-faktor yang mendorong terjadinya intimidasi serta implikasi psikologis jurnalis yang menerima tindakan intimidasi dari narasumber. Manfaat penelitian ini yang diharapkan adalah memberikan gambaran dan pengetahuan kepada para calon jurnalis khususnya yang berada di daerah, agar dapat melakuakan tindakan antisipatif saat mereka menjalankan tugasnya sebagai jurnalis di daerah.

Bourdieu dalam (Herwinarko, 2010) banyak berbicara mengenai bagaimana bahasa membentuk relasi kuasa dalam suatu masyarakat. Bahasa sarat dengan sebuah kepentingan. Menurut Bourdieu, manusia dibentuk oleh nilai-nilai sosial yang terbentuk melalui proses sosialisasi yang cukup lama di lingkungan dimana ia lahir dan tumbuh kembang. Pada akhirnya, akumulasi nilai tersebut diinternalisasi dan menjadi cara pikir dan perilaku yang dihayati. Perilaku tersebut akhirnya berpola dan menjadi pedoman pengetahuan yang tak tersadari menjadi semacam perilaku rutin kita dan berfungsi sebagai matriks-matriks dari pemikiran dan tindakan yang dilakukan anggota dalam masyarakat tertentu. Hal ini yang dikenal dengan istilah Habitus. 
Istilah tersebut juga dipahami sebagai sebuah arena pengungkapan perwatakan dalam ruang sosial. Ruang ini merupakan suatu medan sosial yang di dalamnya, para anggotanya membentuk suatu sistem hubungan berdasarkan atas pertaruhan kekuasaan yang bermakna dan diinginkan oleh ruang sosial itu sendiri. Habitus adalah sebuah ungkapan penanaman nilai yang tak tersadarkan dari orang-orang yang berkepentingan dalam ruang sosial ini. Habitus merupakan tatanan tingkah laku yang digunakan untuk mendiferensiasi satu kelas sosial dengan satu kelas sosial yang lain. Dalam hal ini adalah kelas yang mendominasi dan kelas yang terdominasi.

Bourdieu menyatakan bahwa relasi kekuasaan itu biasa menimbulkan apa yang disebut dengan kekerasan simbolik. Hal ini merupakan hasil pemaksaan sistem simbolisme dan makna dari budaya dominan terhadap kelompok yang didominasi. Kekerasan simbolik dilegitimasi oleh mediasi kesepakatan yang tidak dapat diberikan dari pihak yang mendominasi kepada pihak yang terdominasi.

Kekerasan simbolik dapat dibagi menjadi dua bentuk yakni eufemisme dan sensorisme. Eufemisme adalah kondisi dimana kekerasan simbolik bekerja secara halus dan tidak nampak. Hal tersebut terjadi ketika orang tidak sadar dan tidak tahubahwa mereka sedang mengalami tindakan kekerasan. Mereka sama sekali tak memiliki daya jika mereka sebenarnya sedang dikelabui. Sensorisme menganggap bahwa kekerasan simbolik yang mereka kerjakan merupakan suatu bentuk pelestarian nilai yang dianggap "moral kehormatan". Mereka paham bahwa mereka (pihak terdominasi) diperalat untuk kepentingan tertentu. Akan tetapi, mereka merasa itu baik dan hal itu normal.

Pemikiran Bourdieu mengenai kekerasan simbolik ini juga dapat diinterpretasikan bahwasanya segala bentuk kekerasan yang paling sulit untuk deskripsikan secara nyata dan sulit juga untuk dientaskan karena berjalan dengan aktivitas diskursus. Sebutan simbolik mengacu pada dampak kekerasan yang tidak dapat termanifestasikan sebagaimana kekerasan yang biasa dilakukan secara fisik dengan segera.

Kekerasan simbolik yang terjadi diperkuat dengan simbol-simbol terutama petunjuk non verbal. Seperti contohnya adalah parabahasa (aksen, tekanan suara, tempo suara, nada suara yang membentak-bentak, intonasi yang meninggi) dan ekspresi wajah. Termasuk di dalamnya yakni pengaduan ke pihak yang berwajib. Hal ini dilakukan dengan tujuan yakni menyakiti hati dan merugikan kepentingan orang atau kelompok tersebut (yang terdominasi).

Kaitannya dengan perilaku intimidatif kepada jurnalis daerah di Kota "A" tersebut adalah bahwa sebenarnya teori ini dapat dikatakan bisa relevan. Memang benar bahwa perlakuan yang dilakukan oknum instansi tersebut boleh dikatakan sudah menjurus pada kekerasan yang sifatnya fisik dan nyata, yakni pada peristiwa penamparan kepada jurnalis tersebut. Namun demikian, sifat arogan dan jumawa yang ditunjukkan sebelum peristiwa fisik tersebut, merupakan bukti bahwa di satu pihak ada yang merasa terganggu (yakni pihak yang mendominasi) dengan adanya pemberitaan pungli tersebut, yang dilakukan oleh pihak jurnalis (yang terdominasi).

\section{Kekerasan Verbal dan Non Verbal}

Dalam tinjauan psikologi, kekerasan verbal (tindakan kekerasan melalui penggunaan kata-kata/bahasa) dianggap lebih berbahaya dibandingkan kekerasan fisik (tindakan kekerasan menggunakan cara - cara fisik seperti memukul, menampar, menendang atau cara-cara agersif lainnya). Menurut Djaprie dalam (Fajri, 2019), kekerasan verbal memiliki dampak yang lebih buruk daripada kekerasan yang dilakukan dengan cara-cara fisik.

Mengapa demikian? Alasannya adalah luka sebagai akibat kekerasan yang dilakukan secara fisik masih mampu diobati dengan berbagai jenis obat-obatan. Akan tetapi, kekerasan verbal memerlukan pemulihan yang cenderung lebih lama melalui terapi dan pendampingan 
karena sifatnya yang abstrak. Kekerasan verbal beririsan dengan kekerasan psikologis atau psikis. Sebagai contoh, seseorang yang diejek, dihina, dipermalukan, dimarahi disertai dengan non verbal yang bersifat parabahasa seperti bentakan, intonasi yang tinggi, tekanan suara yang keras, apalagi dilakukan secara terus menerus, pada akhirnya psikologisnya akan terganggu.

Kekerasan verbal biasanya dilakukan pelan-pelan. Seseorang mungkin pada awalnya merasa tindakan itu pada awalnya memakluminya. Namun demikian, lambat laun akan membentuk suatu perasaan ketidaknyamanan yang menyebabkan emosi akan mudah terganggu, dan seiring dengan berjalannya waktu, akan membentuk perasaan dendam atau melampiaskannya kepada orang lain dengan cara yang sama di kemudian hari, apabila sudah memperoleh kekuatan atau kesempatan.

Terlebih lagi bila pihak yang melakukan kekerasan verbal ini telah menemukan orang atau sekelompok orang yang dianggap lebih lemah dari dirinya secara posisinya. Mereka akan cenderung melampiaskannya dengan kata-kata yang bisa jadi kasar, atau kata-kata yang cenderung merendahkan orang lain. Kekerasan verbal dilakukan agar pihak yang melakukannya dapat mendominasi situasi lingkungan dimana kondisi tidak menguntungkan dirinya. Jika diperlukan kekerasan verbal ini diiringi dengan kekerasan fisik. Dengan demikian, rasa percaya diri dari pihak yang melakukannya akan meningkat, walaupun dengan cara yang sama sekali salah.

\section{Intimidasi terhadap Jurnalis}

Pengertian intimidasi adalah perilaku agresif yang disengaja untuk membuat tekanan kepada orang lain atau sekelompok orang, secara fisik maupun psikologis, yang umumnya dilakukan secara berulang-ulang (Randall, 2008). Definisi lain dari intimidasi adalah suatu tindakan untuk memaksa orang lain untuk berbuat sesuatu hal tertentu, yang mana pelakunya mendapatkan manfaat atas perbuatan tersebut (Lukito, R., \& Adnan, 2008).

Profesi jurnalis sebenarnya rentan terhadap gangguan mental sebagai akibat dari perlakuan intimidatif. Menurut Suwarjono, Ketua AJI saat itu menyatakan bahwa hendaknya perusahaan media di tempat para jurnalis bekerja, hendaknya memperhatikan perlindungan bagi para jurnalisnya agar supaya terhindar dari resiko gangguan psikologis. Misalnya membuat aturan kerja yang jelas supaya jurnalis bekerja tetap ada batasnya (Amalia, 2017).

Pekerjaan jurnalis memang memiliki banyak resiko. Sumber dari resiko ini dapat berupa faktor dari luar maupun tekanan dari dalam. Faktor dari luar bisa berbentuk ancaman dari pihak narasumber, tindakan kekerasan fisik dari oknum, juga situasi atau kondisi yang sedemikian sulit seperti peperangan, bencana alam, atau kondisi lingkungan serta geografis. Tekanan dari luar bisa berwujud seperti tingginya kebutuhan kecepatan penyajian informasi serta persaingan untuk mendapatkan informasi secara eksklusif, gaji yang tidak mencukupi, kemudian diperparah dengan jam kerja yang tidak ada batasnya.

Dalam Situs Dart Center, Profesor Psikologi dari Universitas Tulsa, Amerika Serikat, Elana Newman, menyatakan bahwa hasil penelitiannya menunjukkan sebanyak $90 \%$ wartawan terpapar peristiwa traumatis, seperti perang, pembunuhan, kecelakaan, kerusuhan massal, bencana alam dan peristiwa lainnya, telah menyebabkan ganggguan stress pasca traumatik (PTSD), depresi, dan bahkan penyalahgunaan zat.

Sebanyak 4 sampai dengan 59 \% jurnalis mengidap PTSD (Post Traumatic Stess Disorder) sebagai akibat perlakuan intimidatif dimasa perang dan kerusuhan massal. Selebihnya kurang dari $21 \%$ mengalami depresi dan $14 \%$ mengalami ketergantungan alkohol (Amalia, 2017).

Dari semua faktor diatas, maka sesungguhnya perlakuan intimidasi adalah faktor yang berperan cukup besar dalam mendorong terjadinya gangguan psikologis para jurnalis. Perlakuan intimidatif yang menimpa para jurnalis bisa berbentuk fisik atau berbentuk mental 
verbal. Intimidasi berbentuk fisik dilakukan dengan cara perampasan dan perusakan peralatan wartawan seperti kamera, telepon seluar dan perusakan kartu memori.

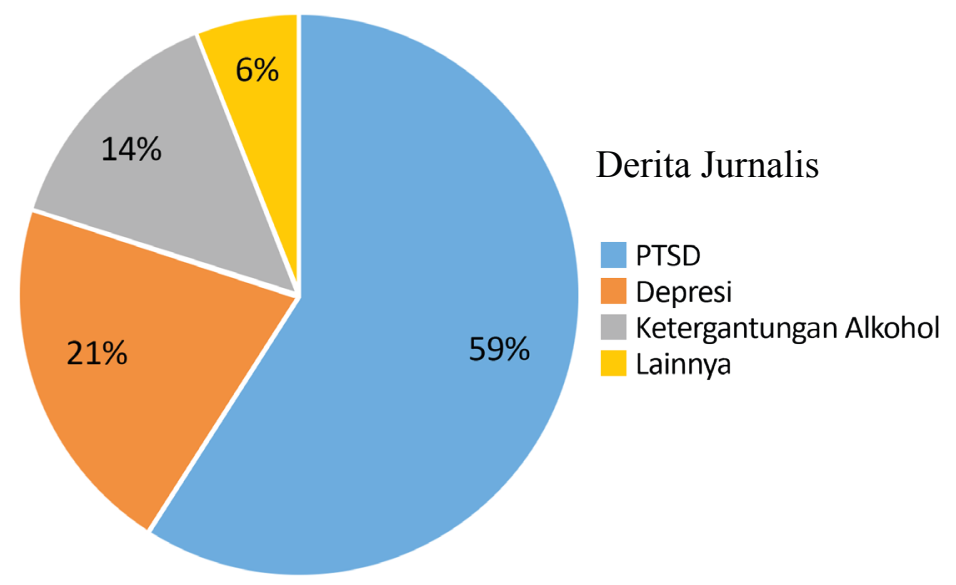

Gambar 1. Derita Jurnalis dalam Menjalankan Tugasnya.

Sumber: (Amalia, 2017)

Tindakan fisik seperti pengeroyokan, pemukulan dan penamparan, bahkan sampai dengan penculikan dan pembunuhan. Sementara itu, tindakan berupa kekerasan verbal bisa berupa ancaman yang telah disebut sebelumnya, pelecehan, penghinaan dan bahkan pelaporan ke pihak berwajib dengan UU ITE. Perlakuan intimidasi ini sendiri justru banyak ditemui pada jurnalis di daerah dan jarang ditemui di Jakarta. Alasannya adalah bahwa para jurnalis di Jakarta lebih memiliki pemahaman akan hak-hak mereka dan didukung oleh organisasi kewartawanan dibanding para jurnalis yang ada di daerah.

Disamping itu, agar dapat terhindar dari intimidasi, maka perlu pula untuk meningkatkan kompetensi jurnalis. (Wijaya \& Yudiningrum, 2016) menyatakan untuk meningkatkan kompetensi jurnalis dapat dilakukan dengan cara yakni sebagai berikut; Pertama, meningkatkan keahlian jurnalis dengan pelatihan-pelatihan, kursus, seminar atau lokakarya. Materi yang perlu dipahami oleh jurnalis meliputi cara mengajukan pertanyaan yang baik kepada narasumber, etiket dan etika, pengetahuan tentang undang-undang perlindungan bagi jurnalis, kemampuan menulis dan bahasa asing.

Kedua, memantau dan melakukan evaluasi terhadap kinerja jurnalis. Hal ini diharapkan dapat mendorong jurnalis untuk lebih berhati-hati dalam menjalankan tugas. Memaksimalkan kerja pemantauan dan mengevaluasi proses dan hasil kerja para jurnalis dapat pula dilakukan oleh lembaga media, agar supaya sesuai dengan target dan standar operasional jurnalistik.

Ketiga, pemberian apresiasi yang lebih sering dilakukan. Dengan demikian, hal tersebut dapat memberikan motivasi dan penyemangat bagi para jurnalis. Pemberian apresiasi berupa penghargaan dalam bentuk uang, kendaraan atau rumah, baik oleh pemerintah atau pihak swasta perlu dikaukan secara obyektif dan menyesuaikan dengan kecukupan dana yang dimiliki. Selain itu, perlu pula diadakan ajang kontes atau festival di bidang jurnalistik. Dengan demikian, iklim pers di Indonesia diharapkan menjadi lebih sehat.

Keempat, sebaliknya, perlu pula adanya pemberian sangsi sebagai upaya pembinaan atas jurnalis yang melanggar prosedur kerja. Oleh karenanya, perlu dilakukan secara bertahap, selektif, edukatif dan obyektif. Yang dimaksud bertahap adalah memberi sangsi baik lisan dan teguran dari yang paling ringan sampai dengan sangsi PHK. Selektif yakni memberikan sangsi berdasarkan pelanggaran yang dilakukan. 
Kelima, meningkatkan kesejahteraan para jurnalis. Idealnya, honor atau gaji bagi jurnalis pemula yang pantas pada tahun 2018 sebesar Rp. 8 jutaan. Namun demikan, gaji rata-rata reporter di perusahaan media hanya berada di antara Rp. 4 Juta - Rp. 5 Juta. Hal ini tentu berkontribusi pada kualitas penerapan standar komptensi jurnalis, yang berujung pada perilaku jurnalis yang tidak professional. Walaupun permasalahan ini sangat tidak terkait dengan keuangan perusahaan media, bila tidak ditangani dengan baik maka kondisi insan pers yang tidak professional akan terus berlangsung di negeri ini.

Oleh karena itu, perusahaan yang mempekerjakan jurnalis perlu memenuhi ketentuan Undang-Undang Ketenagakerjaan mengenai standar kesejahteraan jurnalis sebagai karyawan. Upah yang diberikan minimal setara dengan upah minimum Kota/Kabupaten, ditambah berbagai tunjangan. Disamping itu, pihak perusahaan media sudah seharusnya melakukan diversifikasi sumber pendapatan dan tidak hanya bergantung pada iklan dan penjualan media secara fisik. Dengan meningkatnya kesejahteraan jurnalis, maka diharapkan para jurnalis akan merasa terlindungi dalam melaksanakan kegiatannya.

Keenam, hal ini yang paling penting, yakni optimalisasi advokasi para jurnalis. Kasus kekerasan yang sering terjadi di Indonesia, seperti kasus pembunuhan Udin, wartawan Bernas tahun 1996, atau kasus Naimullah, jurnalis Harian Sinar Pagi, yang ditemukan tewas di Kalimantan Barat, sampai dengan Muh. Jamaluddin, juru kamera TVRI yang hilang di Provinsi Aceh pada tahun 2003. Hal ini tentunya memberikan kabar yang memprihatinkan bagi dunia jurnalistik dan pers serta iklim demokrasi di Indonesia. Oleh karenanya, perlu pendampingan yang intensif bagi jurnalis saat menghadapi ancaman dan intimidasi. Pendampingan sebaiknya bersifat menyeluruh semenjak proses awal sampai dengan akhir. Advokasi harus dilakukan setelah proses pendampingan mediasi antar bersengketa.

Terakhir adalah mengoptimalkan penerapan standar kompetensi jurnalis. Hal ini dapat ditempuh melalui uji kompetensi jurnalis. Masih belum banyak jurnalis di Indonesia yang mengikuti uji kompetensi sebagai seorang jurnalis. Hal ini dapat disebabkan oleh sosialisasinya yang kurang atau memang penyelenggaranya masih kurang. Walaupun sebenarnya tidak terlalu terkait secara langsung pengaruhnya pada tindakan intimidasi jurnalis, kompetensi jurnalis tetap diperlukan khususnya bagi jurnalis daerah, sebagai antisipasi jurnalis untuk meminimalisir ancaman karena kurang profesionalnya jurnalis.

Tabel 1. Peningkatan Kompetensi Jurnalis

\begin{tabular}{|r|l|l|}
\hline No & \multicolumn{1}{|c|}{ Kompetensi } & \multicolumn{1}{c|}{ Keterangan } \\
\hline 1. & Peningkatan Keahlian & Dengan pelatihan dan kursus-kursus \\
\hline 2. & Evaluasi Kinerja & Disesuaikan dengan Standard Operasional Jurnalis \\
\hline 3. & Pemberian Apresiasi & Dalam bentuk uang/kendaraan atau rumah \\
\hline 4. & Pemberian Sangsi & Jika melanggar prosedur kerja dan kode etik \\
\hline 5. & Peningkatan Kesejahteraan & Pemberian gaji diatas upah minimum dan tunjangan \\
\hline 6. & Optimalisasi Advokasi & Pendampingan hukum saat terjerat kasus \\
\hline 7. & Penerapan Standard Kopetensi & Dengan mengikuti uji kompetensi sebagi seorang jurnalis \\
\hline
\end{tabular}

\section{METODE}

Metode yang digunakan penelitian ini adalah deskriptif kualitatif. Teknik pengumpulan data yang digunakan adalah wawancara dengan para jurnalis yang menjadi korban kekerasan dan intimidasi. Obyek penelitiannya adalah intimidasi yang dialami oleh para jurnalis lokal di kota tersebut. Penelitian ini menginvestigasi jenis-jenis intimidasi, faktor-faktor yang mendorong perlakuan intimidasi terhadap jurnalis, dan implikasi psikologis yang dialami oleh 
para jurnalis tersebut.

Menurut Williams dalam (Hidayat, 2018), terdapat 5 (lima) perbedaan antara pendekatan kuantitatif dan kualitatif. Lima perbedaan tersebut antara lain: Pertama, memiliki sifat realitas, pendekatan kuantitatif memandang realitas sebagai sesuatu tunggal, konkrit, teramati, dan dapat difragmentasi. Sebaliknya pendekatan kualitatif melihat realitas majemuk, hasil konstruksi dalam pandangan menyeluruh. Dengan demikian, peneliti kuantitatif lebih spesifik, percaya langsung pada obyek generalis, meragukan dan mencari fenomena pada obyek yang realitas yang terdapat pada penelitian kualitatif.

Kedua, interaksi antara peneliti dengan obyek penelitiannya, pendekatan kuantitatif melihat sebagai independen, dualistik dan mekanistik. Sebaliknya pendekatan kualitatif melihat sebagai proses interaktif, tidak terpisahkan dan bersifat partisipasif. Ketiga, posibilitas generalis, bahwa pendekatan kuantitatif bebas dari ikatan konteks dan waktu (nomothetic statements). Sebaliknya pendekatan kualitatif terikat dari ikatan konteks dan waktu (idiographic statements).

Terakhir adalah posibilitas kausal, bahwa pendekatan kuantitatif selalu memisahkan antara sebab nyata temporal simultan yang mendahuluinya sebelum akhirnya menghasilkan konsekuensi. Sedangkan pendekatan kualitatif selalu meniadakan adanya hubungan sebab dengan akibat, terlebih secara simultan.

Inti dari penelitian kualitatif adalah pada proses dan pemaknaan hasilnya yang didapat dari pengumpulan data baik itu dengan wawancara, diskusi kelompok terfokus, maupun observasi, baik secara partisipatif maupun secara non partisipan. Konsentrasi riset kualitatif terletak pada elemen individu, objek, maupun lembaga sosial, serta relasi atau interaksi yang terdapat di antara elemen-elemen tersebut, dalam usahanya untuk memahami suatu peristiwa atau kejadian, perilaku, atau fenomena sosial yang dijelaskan oleh Mohamed, Abdul Majid \& Ahmad dalam (Ardianto, 2019).

Alasan menggunakan metode kualitatif dalam penelitian ini adalah bahwa pengalaman jurnalis yang menerima intimidasi dalam kasus pungli di Kota "A"ini merupakan pengalaman yang bersifat pribadi, yang dimaknai satu jurnalis dengan jurnalis yang lain berbeda-beda. Hal tesebut tidak mungkin di generalisasi. Pengalaman intimidasi tersebut juga tentunya menimbulkan trauma psikologis. Dampak atau implikasi tersebut juga berbeda kadarnya antara satu jurnalis dengan jurnalis lainnya. Hal tersebut tentunya sejalan dengan ciri penelitian kualitatif yang terikat dengan pernyataan idiografis.

Disamping itu, riset ini bukanlah merupakan pernyataan inferensi atas pengalaman seluruh jurnalis yang mengalami kejadian yang sama pada kasus tertentu. Riset ini berusaha mengungkapkan secara mendalam mengenai pengalaman unik dan tersendiri dari sedikit jurnalis yang menerima perlakuan intimidasi oleh oknum, tanpa berpretensi menggeneralisir bahwa semua jurnalis mengalami perasaan yang sama, sebagai tindakan yang berupa stimulan yang sama (intimidasi) pada kasus di lokasi yang lain.

\section{HASIL DAN PEMBAHASAN}

Dalam pertanyaaan - pertanyaan awal yang diajukan kepada para jurnalis mengenai pemahaman mereka tentang jenis intimidasi atau kekerasan, maka di dapat hasil sebagai berikut; Jenis-jenis kekerasan yang dipahami oleh jurnalis dapat dikategorikan menjadi empat yakni fisik, psikologis, ekonomi, pelecehan seksual. Hal tersebut penulis tanyakan saat berbincang dengan tiga jurnalis yang terlibat di kasus pungli di Kota " $A$ " tersebut.

"Menurut saya kekerasan yang biasa dialami oleh kami-kami ini sebagai wartawan, ada yang sifatnya fisik seperti penamparan dan tendangan, kalau maki-makian dan 
teror - teror lewat telpon gitu masuknya apa ya? ...ehmm ya pengaruhnya ke jiwa kali ya? (maksudnya Psikologis-Penulis). (disambung dengan informan kedua)...oh iya.. lalu ada juga yang bentuknya ancaman dari bos, jika kita ga nyampe target untuk bisa dapat info dari bos dari instansi pemerintah tersebut tentang pungli itu...ga akan dapat insentif...kalau gitu masuk ke kategori kekerasan apa ya pak?..motif ekonomi kali ya pak? (infoman ketiga)....dan kalau yang temen kita yang cewek, ya..biasalah...menjurus ke ngarah-ngarah ke pelecehan, seperti ngajak nemenin ke mana...misal ke karaoke, makan di restoran atau bahkan hotel, nanti baru dijawab pertanyaannya..."(Totok, Wawancara. 6 November 2019)

Dari jawaban tersebut, maka dapat disimpulkan bahwa para jurnalis ini memiliki pengetahuan tentang konsep kekerasan. Setidaknya pernah mendapatkan pengalaman mendapatkan perlakuan intimidasi atau kekerasan, baik yang dialaminya sendiri atau oleh temannya. Kekerasan fisik yakni ditandai dengan perbuatan yang mengakibatkan rasa sakit atau luka berat. Contohnya ditampar, dipukul, ditendang, dirampas peralatan liputannya, atau percobaan pembunuhan.

Kekerasan psikologis ditandai dengan bentuk ucapan yang menyakitkan, perkataan dengan nada dan intonasi yang tinggi, penghinaan, ancaman yang pada akhirnya mengakibatkan ketakutan, kehilangan semangat dan rasa percaya diri, perasaan lemah secara psikologis yang dialami terutama oleh para jurnalis. Sedangkan khususnya bagi para jurnalis wanita, terkadang mengalami tekanan seperti dimana narasumber "mengiming-imingi" memberi informasi, namun harus mau mengikuti kemauan narasumber untuk menemani makan atau karaoke.

Sedangkan intimidasi dari dalam atau dari perusahaan dimana para jurnalis bekerja adalah lebih kepada ancaman tidak akan diberikan insentif jika tidak memenuhi target pemberitaan yang memiliki nilai jual, kegagalan menemui narasumber, atau tidak memenuhi deadline. Lebih parah lagi jika terdapat pemotongan gaji atau ancaman Pemutusan Hubungan Kerja (PHK) jika memang kinerja mereka dianggap menurun atau tidak mumpuni lagi sesuai ekspektasi perusahaan.

Berdasarkan hasil temuan dari wawancara yang dilakukan peneliti pada para jurnalis tersebut, didapat intimidasi yang berbentuk verbal dan non verbal. Bentuk intimidasi verbal yang diterima oleh para jurnalis tersebut berupa lontaran caci maki dengan kata-kata yang menyakitkan, ujaran-ujaran yang tak pantas dengan menggunakan bahasa daerah mereka. Sementara itu, bentuk intimidasi non verbal yang diterima mereka adalah ekspresi wajah dengan tatapan mata yang terbelalak, air muka yang memerah, gesture dengan memukul-mukul benda, tendangan, tamparan bahkan merampas alat seperti telepon seluler, alat tulis dan kamera. Pada akhirnya, jurnalis juga mendapatkan ancaman teror pembunuhan melalui SMS atau telepon gelap. Hal ini diungkapkan oleh salah seorang jurnalis yang terlibat dalam kasus penganiayaan dan intimidasi pada kasus pungli tersebut. Beliau bernama Anwar (nama samaran).

"Setelah kejadian pengusiran dan penamparan tersebut, diluar dugaan, malamnya kami menerima SMS. Saya pun ga tahu, darimana mereka dapat nomor hp saya. Isinya ..gini..."kalo lo masih macem-macem lagi, nanya-nanya urusan gituan ke kantor...lo akan berurusan ama gw... berikut anak bini lo...inget!". ...karena saya takut, ya cepetcepet saya hapus aja pak "(Anwar, Wawancara. 6 November 2019)

Pertanyaan selanjutnya yang diajukan kepada jurnalis adalah asumsi mereka mengenai apa saja yang mendorong pemicu intimidasi kepada mereka selaku jurnalis. Jawabannya adalah sebagai berikut; pertama, adalah kurangnya sikap professional dari kalangan jurnalis itu sendiri. Jurnalis yang menjadi salah seorang informan penelitian ini pun mengakui hal ini; "Bisa juga karena wartawannya tidak mengerti, bagaimana menjadi wartawan yang profesional. Itu kita harus akui, bahwa dalam beberapa kasus kita temukan seperti itu"(Anwar, Wawancara. 6 November 2019) 
Namun demikian, informan ini pun juga berpendapat, tak seharusnya polisi melakukan tindakan keras pada jurnalis, dengan alasan bahwa jurnalis tersebut tidak beretika dalam melakukan pencarian berita dan saat memberitakan kejadian tersebut dengan alasan pencemaran nama baik. Informan lain menyatakan bahwa;

"Masalahnya adalah arogansi sih... dari pihak perusahaannya. Mereka khawatir jika tindakan kesalahan mereka terekspos di media. Pihak polisi juga arogan...mereka juga takut kalau tindakan mereka ke para demonstran terliput oleh kita-kita sebagai wartawan, dan akhirnya itu dianggap mencemarkan nama baik kepolisian"(Wira, Wawancara. 6 November 2019)

Menurutnya, bahwa terjadinya kekerasan fisik antara polisi dengan jurnalis adalah kurangnya pemahaman polisi mengenai undang-undang pers yang melindungi para jurnalis. Selain itu, tidak selesainya kasus intimidasi jurnalis di ranah hukum karena korban lebih memilih jalur damai. Itu karena permintaan perusahaan tempat dia bekerja. Jurnalis yang menjadi korban pun kadangkala akhirnya mengambil keputusan damai dengan pelaku tindak kekerasan, walaupun jurnalis tersebut telah melapor ke Aliansi Jurnalis Independen (AJI).

Kekerasan yang diterima oleh para jurnalis biasanya dengan alasan karena merekam aksi brutal dari aparat kepolisian terhadap para demonstran. Pihak aparat kepolisian biasanya tidak menginginkan jurnalis merekam aksi tindakan kasar mereka kepada para pengunjuk rasa.

"Saya rasa mengapa ada kekerasan dan penindasan pada wartawan karena aparat tidak terima perlakuan mereka terekam dalam kamera para wartawan. ...padahal harusnya kan mereka tahu dong..hal itu ga boleh dilakukan mengingat kami-kami ini dilindungi oleh undang-undang pers lho!!”(Anwar, Wawancara. 6 November 2019)

Kekerasan dalam persepsi para informan penelitian ini, lebih cenderung penyerangan secara fisik. Menurut mereka kekerasan yang mereka lakukan sebenarnya tidak patut untuk dilakukan. Apalagi yang melakukan itu adalah oknum yang berpihak ke narasumber atau bahkan dari pihak kepolisian sekalipun.

Dalam pengamatan mereka, selama mereka bertugas sebagai jurnalis, kekerasan fisik yang mereka terima cenderung semakin meningkat. Sesungguhnya kenyataan ini boleh dikatakan memprihatinkan. Antar mereka saling bertukar cerita, dan akhirnya ditemukan berbagai cerita yang menceritakan kepedihan-kepedihan yang mereka alami selama menjalankan tugas. Termasuk di dalamnya adalah ketika mereka meliput kasus pungli di salah satu instansi pemerintah daerah tersebut. Perbuatan semacam ini yang telah mereka alami sesuangguhnya tergolong perbuatan kriminal dan sudah seharusnya diproses secara hukum.

Adapun faktor-faktor yang mendorong perlakuan intimidasi kepada jurnalis lokal di kota tersebut adalah sebagai berikut. Pertama, terjadinya kesalahpahaman antara narasumber dan jurnalis. Jurnalis kurang dapat menjelaskan maksud pertanyaan yang diajukan ke narasumber. Bahasa yang digunakan terkesan mungkin kurang sopan menurut persepsi narasumber. Pertanyaan yang diajukan terkesan memojokkan narasumber dan cenderung menuduh narasumber yang melakukan perbuatan tercela tersebut. Hal tersebut dinyatakan oleh salah seorang informan;

"Saya pernah waktu itu bertanya sama orang yang ada diinstansi tersebut, sebelum peristiwa pengusiran oleh oknum. Awalnya proses wawancara sih berjalan lancar, walau dijawab dengan jutek dan terkesan menjawab seadanya. Pas saat ditengah-tengah wawancara, ketika saya nanya seperti apakah Bapak tahu bahwa kasus pungli ini sudah jadi rahasia umum di masyarakat sekitar...bapak yang bersangkutan malah menyahut.. lho kok kamu nanyanya ga sopan ya?....'(Totok, Wawancara. 6 November 2019)

Faktor lainnya yang memicu intimidasi adalah saat berita tersebut dimuat dan 
dipublikasikan di media lokal tersebut, cenderung menggunakan judul yang bombastis dan terlalu memojokkan. Isi yang diberitakan sebenarnya sesuai dengan transkrip wawancara yang sudah dibuat dan disepakati oleh narasumber dan jurnalis tersebut. Namun demikian, ketika hasilnya telah diedit dan diunggah ke media, narasi yang diungkapkan telah "sedikit banyak" dibumbui dengan kata-kata yang menyudutkan. Hal ini sesungguhnya berkait erat dengan pemahaman terhadap kode etik dan kompetensi jurnalis tersebut dalam mengolah berita tersebut.

Faktor lain yang memicu amarah narasumber sampai mereka melakukan intimidasi adalah perilaku jurnalis yang mengambil gambar tanpa ijin, tidak mengindahkan keselamatan akan dirinya sendiri saat meliput demonstrasi atau tawuran, dan mencoba melawan pihak aparat demi dalih membela diri dengan cara-cara yang brutal. Faktor diluar aspek internal jurnalis itu sendiri adalah ketidaktahuan masyarakat umum dan narasumber mengenai tugas dan kewajiban jurnalis saat meliput kejadian di lapangan. Hal ini sering menjadi faktor pemicu intimidasi dari pihak masyarakat atau narasumber kepada sang jurnalis.

Dari beberapa jurnalis yang menjadi informan penelitian ini ketika ditanyakan hal-hal apa saja yang dirasakan saat mereka memperoleh perlakuan intimidasi, yakni perasaan terpukul yang amat mendalam, rasa takut untuk kembali menjalankan tugasnya sebagai jurnalis terutama ketika harus meliput peristiwa seperti demonstrasi, bentrokan, eksekusi lahan, pertikaian di pengadilan atau tawuran. Disamping itu, hilangnya rasa percaya diri yang bermuara pada menurunnya kinerja di lapangan saat bertugas, rasa sakit hati yang berujung pada dendam yang dirasa berkepanjangan.

"Seumur-umur jadi wartawan, baru kali ini saya ditampar dan dimaki-maki. Saya salah apa ya? Perasaan kemarin nanya baik-baik aja...mungkin saya pas ambil gambar ga ijin kali ya? Ahh lupa...tapi setelahnya nahan rasa sakitnya bisa semingguan lebih, akibatnya juga ga ada gairah juga masuk kantor atau ngliput... sempet kayak ga pede juga sih pas ketemu temen-temen kantor sesama wartawan. Males juga kalau ditanyatanya gimana rasanya, dah gitu..parno aja kalau nanti ada yang ngejek-ejek..untungnya ga ada yang berbuat seperti itu ke saya deh"(Wira, Wawancara. 6 November 2019)

Pertanyaan selanjutnya adalah mengenai pemahaman umum, dampak atau implikasi secara umum dari kekerasan atau intimidasi yang diterima. Para informan berpendapat bahwa dampak dari kekerasan dapat berupa sakit atau kerugian secara fisik, ada pula yang bersifat psikis. Dampak fisik yang sifatnya segera yang dialami oleh terintimidasi adalah luka - luka, memar, sampai dengan gegar otak. Disamping itu, dampak fisik yang baru terasa jangka panjang adalah masalah pencernaan, sakit kepala, sakit punggung, infeksi pernafasan dan bahkan insomnia.

Kekerasan dapat juga menjauhkan para jurnalis yang terpapar korban, dari keluarga dan teman-temannya. Tanpa sadar, jurnalis yang menjadi korban menarik diri dari pergaulan sosialnya karena rasa rendah diri akibat rasa terluka atau luka fisik sebagai akibat perilaku intimidasi. Salah seorang informan jurnalis yang peneliti temui, memyatakan hal yang berikut ini.

"Entah kenapa yaa...sejak saya ditampar sama oknum dari pihak lembaga tersebut, kayak ada yang aneh gitu..males untuk berhubungan dengan temen-temen seprofesi, males juga kalau ditanya ini itu, pengennya di rumah aja dan males keluar. Apalagi pas diancam lewat hape...jadi takut untuk ngomong banyak...takut salah ngomong juga. Tapi karena kelamaan di rumah dan ngga ada penghasilan...yahhh..lama-lama depresi dan ujung-ujungnya jadi kepikiran untuk bunuh diri..haha" (Anwar, Wawancara. 6 November 2019)

Beberapa informan yang ditanyakan tentang dampak kekerasan atau intimidasi yang 
mereka terima selama mereka menjalankan tugas pada saat kasus pelaporan adanya dugaan kasus pungli di instansi tersebut. Mereka menjawab bahwa ada perasaan cemas yang berlebih dan trauma secara psikologis pasca kejadian tersebut. Beberapa hari pasca peristiwa itu, ada yang sempat terpikir untuk berhenti berkarir sebagai jurnalis, ada pula yang berharap supaya anak dan keturunannya tidak ada yang memilih berkarir sebagai jurnalis.

Namun demikian, ada pula yang memiliki sikap sebaliknya. Beberapa informan yang lain justru merasa lebih tertantang untuk lebih berani dan bersemangat untuk meneruskan karirnya sebagai jurnalis. Mereka ini beranggapan, dengan resiko pekerjaan seperti inilah yang membuat mereka semakin imun/kebal dan lebih tertempa untuk menjadi jurnalis yang profesional. Sementara itu, ada pula yang berpendapat bahwa kejadian intimidasi ini, justru menyadarkan akan arti penting perlunya meningkatkan kompetensi ketrampilan sebagai jurnalis dalam menghadapi situasi di lapangan dan meningkatkan seni "bertanya" pada narasumber, tanpa harus "memojokkan" narasumber, sehingga perilaku intimidasi ini dapat dihindarkan.

"Entah kenapa ya?..memang pas awal-awal pasca kejadian, rasanya sakit hati banget... ya Alloh...kenapa kok gini-gini banget ya nasib hambaMu. Tapi saya pribadi sih langsung ngilangin perasaan-perasaan yang nggak enak dimaki-maki ama oknum tersebut. Positive thinking aja lahh..namanya setiap kerjaan pasti ya ada resikonya... Bapak kan sebagai dosen juga pasti tahu lah...dosen aja ya pasti ada resikonya kan? Misalnya ada orang tua mahasiswa complain. Saya sendiri belajar dari kejadian itu, mencoba introspeksi, kira-kira saya salah apa ya, apa yang kurang dari saya? Saya harus belajar jadi wartawan yang profesional, agar lebih punya harga diri..lebih berdaya lah maksudnya..."(Totok, Wawancara. 6 November 2019)

Pemahaman dalam peraturan dan perlindungan hukum bagi jurnalis perlu ditingkatkan. Seperti yang diketahui bahwa Undang-Undang Informasi Teknologi Elektronika (UU ITE), tidak dapat menjadi penghalang bagi para jurnalis dalam melakukan tugasnya. Harus ada upaya, terutama dari Dewan Pers untuk menimalisasi penggunaan UU ITE sebagai dalil untuk menjerat jurnalis.

Hal ini bisa dipahami bahwa di dalam UU ITE menyebutkan pernyataan "Barang siapa tanpa hak mengambil dan menyebarkan....dan seterusnya", padahal jurnalis memiliki hak untuk melakukan kegiatan tersebut. Pasal 9 Undang-Undang Pers mengatakan bahwa jurnalis dalam tugasnya dilindungi hukum. Oleh karenanya, jurnalis tidak mungkin menjadi target korban dari UU ITE.

Pihak pengelola media yang memperkerjakan jurnalis juga perlu melakukan konsolidasi dan koordinasi dengan dewan pers pusat serta asosiasi atau organisasi jurnalis seperti Aliansi Jurnalis Independen (AJI) untuk meminimalisir meningkatnya intimidasi pada jurnalis di daerah. Penglola media perlu pula membentuk divisi penanganan trauma jurnalis sebagai sarana untuk konsultasi dalam pemulihan psikologis para jurnalis yang mendapatkan perlakuan intimidasi tersebut.

Terakhir adalah perlunya pembinaan yang berkesinambungan dalam meningkatkan kompetensi jurnalis daerah. Hal ini dilakukan sebagai upaya untuk dapat meminimalisir ketegangan, meredakan kesalahpahaman yang biasanya berujung pada tindak kekerasan dan intimidasi. Pelatihan ini dapat diperoleh dengan bekerjasama dengan perguruan tinggi setempat yang menyelenggarakan pendidikan jurnalisme, pihak Lembaga Bantuan Hukum dan Konsultan Psikologi untuk menangani luka psikologis yang diakibatkan perlakuan intimidasi.

\section{SIMPULAN}

Jenis-jenis kekerasan yang menimpa pada para jurnalis lokal antara lain adalah kekerasan yang berupa ancaman, intimidasi yang tergolong kedalam kekerasan verbal. Sedangkan 
kekerasan fisik yang diterima adalah berupa perlakuan yang terlihat adalah dalam bentuk tamparan. Adapun faktor-faktor yang mendorong terjadinya intimidasi pada wartawan lokal adalah berupa ketidakpahaman dalam hal pembelaan diri bila menerima intimidasi atau asan dan kurangnya keahlian dan kompetensi sebagai jurnalis di lapangan. Implikasi dari bentuk perlakuan kekerasan pada wartawan tersebut di Kota "A" yang paling utama yakni berkurangnya kepercayaan diri untuk melanjutkan profesi sebagai jurnalis.

Semua informan yang merupakan jurnalis lokal dari kota tersebut mengakui adanya kekurangan pada diri mereka untuk menjadi jurnalis yang profesional. Mereka merasakan perlunya peningkatan ketrampilan dalam meliput berita di lapangan dan menyusun pertanyaan yang baik sehingga narasumber tidak merasa terpojokkan atau tersinggung. Disamping itu, pemahaman akan regulasi yang melindungi mereka saat bertugas perlu ditingkatkan. Dengan demikian, kemampuan dalam membela diri mereka saat diintimidasi atau terkena perlakuan yang tidak menyenangkan dari pihak atau oknum, dapat ditunjukkan sehingga perasaan waswas dapat lebih meningkat. Sosialisasi yang kurang akan tugas dan tanggung jawab pers pun sebenarnya berkontribusi dalam peningkatan intimidasi dan kekerasan pada insan pers itu sendiri.

\section{DAFTAR PUSTAKA}

Amalia, Z. (2017). Wartawan Rentan Kena Gangguan Mental, AJI: Perlu Refereshing. Diakses pada 29 Oktober 2019, dari Tempo.Co website: https://nasional.tempo.co/read/902640/ wartawan-rentan-kena-gangguan-mental-aji-perlu-refreshing/full\&view $=\mathrm{ok}$

Ardianto, Y. (2019). Memahami Penelitian Kualitatif. Diakses pada 30 Oktober, 2019, dari djkn.kemenkeu.go.id website: https://www.djkn.kemenkeu.go.id/artikel/baca/12773/ Memahami-Metode-Penelitian-Kualitatif.html

Fajri, R. (2019). Psikolog Sebut Kekerasan Verbal Lebih Bahaya Ketimbang Fisik. Diakses pada 28 Oktober 2019, dari Mediaindonesia.com website: https://mediaindonesia.com/ read/detail/228624-psikolog-sebut-kekerasan-verbal-lebih-bahaya-ketimbang-fisik

Gumilang, P. (2018). AJI Kecam Kriminalisasi Jurnalis Terkait Berita BP Batam. Diakses pada 28 Oktober 2019, dari CNN Indonesia website: https:/www.cnnindonesia.com/ nasional/20180218000647-20-276892/aji-kecam-kriminalisasi-jurnalis-terkait-beritabp-batam

Hakim, I. (2013). Upaya Perlindungan Hukum bagi Wartawan dari Tindak Kekerasan pada Saat Menjalankan Tugas Jurnalistik, Studi Kasus di Radio El-Shinta Surabaya, Fakultas Hukum Universitas Brawijaya, Malang. Malang: FH Universitas Brawijaya. Hukum. Studentjournal. Diakses pada from http://hukum.studentjournal.ub.ac.id/index.php/ hukum/article/view/10

Herwinarko, S. (2010). Pierre Bourdieu : Kekerasan Simbolik. Yogyakarta: Penerbit Jalasutra. Hidayat, A. (2018). Penjelasan Lengkap tentang Penelitian Kualitatif. Diakses pada 30 Oktober 2019, dari statistikian.com website: https://www.statistikian.com/2012/10/penelitiankualitatif.html/amp

Independen, A. J. (2013). Catatan Akhir Tahun 2012. Diakses pada 28 Oktober 2019, dari ajiindonesia.or.id website: http://ajiindonesia.or.id/read/article/press-release/168/ catatan-akhir-tahun-2012-aji-indonesia.htm

Lukito, R., \& Adnan, A. (2008). Tradisi Hukum Indonesia (Edisi Pertama). Jakarta: Teras.

Maharani, S. (2019). Demo Mahasiswa Gejayan Memanggil Kembali Digelar di Yogyakarta. Diakses pada 28 Oktober 28 2019, dari Tempo.Co website: https://nasional.tempo.co/ read/1253881/demo-mahasiswa-gejayan-memanggil-kembali-digelar-di-yogyakarta 
Volume 04 Nomor 01 Tahun 2020

DOI: $10.24198 /$ jkj.v4i1.24134

Rahayu, L. (2019). AJI: Sekitar 20 Wartawan Jadi Korban Kekerasan Rusuh 21-22 Mei. Diakses pada 28 October 2019, dari Detik.Com website: https://news.detik.com/ berita/d-4565908/aji-sekitar-20-wartawan-jadi-korban-kekerasan-rusuh-21-22-mei

Randall, C. (2008). Violence: A Micro-Sociological Theory. New Jersey: Princeton University Press.

Warta Ekonomi Online. (2019). Kriminalisasi 2 Wartawan Palangkaraya, Aparat Melanggar Hukum Gunakan UU ITE. Diakses pada 28 Oktober, 2019, dari wartaekonomi.co.id website: https://www.wartaekonomi.co.id/read238181/kriminalisasi-2-wartawanpalangka-raya-aparat-melanggar-hukum-gunakan-uu-ite.html

Wijaya, S. H. B., \& Yudiningrum, F. R. (2016). Meningkatkan Kecerdasan Bangsa Melalui Optimalisasi Penerapan Standar Kompetensi Wartawan. Jurnal Komunikasi Ikatan Sarjana Komunikasi Indonesia. https://doi.org/10.25008/jkiski.v1i2.55 